\title{
Uterine fluid transcriptome as potential non-invasive biomarker for predicting endometrial receptivity
}

3 Aihua $\mathrm{He}^{1,2 \dagger}$, Hong $\mathrm{Wu}^{3 \dagger}$, Yangyun $\mathrm{Zou}^{4}$, Cheng Wan ${ }^{4}$, Jing Zhao ${ }^{1,2}$, Qiong Zhang ${ }^{1,2}$, Nenghui Liu ${ }^{1,2}$, Donge

$4 \mathrm{Liu}^{1,2}$, Yumei $\mathrm{Li}^{1,2}$, Jing Fu ${ }^{1,2}$, Hui Li ${ }^{1,2}$, Xi Huang ${ }^{1,2}$, Tianli Yang ${ }^{1,2}$, Chunxu Hu${ }^{4}$, Zhaojuan Hou ${ }^{1,2}$, Yue

$5 \quad \mathrm{Sun}^{4}, \mathrm{Xin} \mathrm{Dong}^{4}, \mathrm{Jian} \mathrm{Wu}^{4}$, Sijia $\mathrm{Lu}^{4}$, Yanping $\mathrm{Li}^{1,2} *$

$6{ }^{1}$ Department of Reproductive Medicine, Xiangya Hospital, Central South University, Changsha, Hunan,

7 410000, China.

$8{ }^{2}$ Clinical Research Center for Women's Reproductive Health in Hunan Province, Changsha, Hunan, 410000,

9 China.

$10{ }^{3}$ Department of ENT, Xiangya Hospital, Central South University, Changsha, Hunan, 410000, China

$11{ }^{4}$ Department of Clinical Research, Yikon Genomics Company, Ltd., Suzhou, Jiangsu, 215123, China.

12 *For correspondence: liyanp@csu.edu.cn (YPL); lusijia@yikongenomics.com (SJL)

13 † These authors contributed equally to this work

14 


\section{Abstract}

29 Background: The synchrony between the embryo and the receptive endometrium is essential for successful

30 implantation. Therefore, a reliable non-invasive ER prediction method is highly demanded. We aimed to

31 establish a method that could be used to predict endometrium receptivity non-invasively and to evaluate its

32 clinical application potential in patients undergoing IVF.

33 Methods: The non-invasive RNA-seq based endometrial receptivity test (nirsERT) was established by

34 sequencing and analyzing the RNA of uterine fluid from 48 IVF patients with normal ER. Subsequently, 22

35 IVF patients were recruited and analyzed the correlation between the predicted results of nirsERT and

36 pregnancy outcomes.

37 Results: 87 marker genes and 3 hub genes were selected to establish the nirsERT. 10-fold cross-validation

38 resulted in a mean accuracy of $93.0 \%$. A small cohort retrospective observation showed that $77.8 \%(14 / 18)$ of

39 IVF patients predicted with normal WOI had successful intrauterine pregnancies, while none of the 3 patients

40 with displaced WOI had successful pregnancy.

41 Conclusions: nirsERT is potential for a non-invasive, accurate and same cycle testing for ER in reproductive 42 clinic.

43 Funding: Funded by the National Natural Science Foundation of China (grant no. 8187061497) and the

44 National Key Research and Developmental Program of China (grant no. 2018YFC1004800).

45 Clinical trial number: ChiCTR-DDD-17013375.

47 Keywords: Endometrial receptivity, window of implantation, transcriptomic profiling, machine learning, random forest algorithm, non-invasive biomarker. 
medRxiv preprint doi: https://doi.org/10.1101/2021.03.07.21253097; this version posted March 9, 2021. The copyright holder for this preprint (which was not certified by peer review) is the author/funder, who has granted medRxiv a license to display the preprint in perpetuity.

All rights reserved. No reuse allowed without permission.

\section{Introduction}

An ideal synchrony between the embryo and the receptive endometrium is necessary for successful implantation. The period of receptive endometrium, which referred to as window of implantation (WOI), normally occurs during the 19th to 24th day of a normal cycle. Previous studies demonstrated that the pregnancy rate would significantly reduce when implantation is not performed during the WOI $[1,2]$. However, the optimal WOI lasts for less than 48 hours and varies wildly between individuals [3]. Abnormal endometrium receptivity (ER), including WOI shift and pathologic injury, has been observed in numerous patients with repeated implantation failure (RIF) [4-6]. Therefore, an approach of evaluating ER status is in urgent need, especially in the field of assisted reproductive technology (ART).

To fulfill this requirement, several methods had been proposed in the past decades, such as ultrasound examination [7-9], histologic analysis [10], and morphological markers [11-13]. But none had been proven to be an ideal predictor of endometrial receptivity. With the advance in molecular biological technologies, our understanding of molecular mechanism of embryo implantation has been significantly improved. In 2011, a 238 gene endometrial receptivity array (ERA) using RNA expression microarray was published by DiazGimeno et al [14]. The ERA method is capable of identifying different stages of endometrial cycle, which are known as pre-receptive (PR), receptive (RE), and post-receptive (PO). The accuracy and reproducibility was proven to be reliable in subsequent studies [15-17]. Several studies have demonstrated that pregnancy outcomes of patients with RIF and infertile couples with conventional IVF [17, 18] can be improved by personalized embryo transfer (pET) guided by the ERA test. In addition, relevant results indicate that transcriptomic and proteomic markers provide promising approaches for ER assessment. Although numerous differentially expressed genes (DEGs) that are involved in endometrial receptivity have been revealed by previous studies, the overlap between these results is rather poor. One explanation might be that the sample size, individual differences and microarray platforms differ between studies. The next-generation, highthroughput RNA sequencing (RNA-seq) provides another powerful tool for analyzing the whole transcriptome comprehensively. RNA-seq is better than microarray at dynamic range, background noises, and identifying different transcripts $[19,20]$. Another limitation for current diagnostic tools of endometrial receptivity has been the necessity of invasive tissue sampling by endometrial biopsy. The endometrial RNA expression profile could be altered due to the small injuries caused by invasive sampling [21]. Besides, local injury to the endometrium was reported to have a negative impact on implantation [22], therefore, it is inappropriate to perform endometrial tissue sampling test and guide implantation in a same active cycle. It is necessary to develop a non-invasive diagnostic tool to accurately predict WOI.

Uterine fluids is the important medium of communication between embryo and endometrium. It is an admixture of endometrial secretions, plasma transudates, and oviductal fluid [23]. Uterine fluid contains

83 extracellular vesicles, RNAs, DNAs, regulatory proteins, ions, lipids and other bioactive factors and plays an 84 important role in embryo implantation [24]. Thus, high throughput sequencing of uterine fluid provides an 
opportunity to find non-invasive biomarkers of endometrial receptivity for clinical use. Aspiration of uterine fluid prior to embryo transfer does not affect embryo implantation rate [25] also supports the feasibility of developing a non-invasive diagnostic tool based on uterine fluid. However, there are few transcriptional studies related to endometrial receptive markers from uterine fluid. A previous study [26] has identified a 53 candidate genes predictive of endometrial receptivity by using microarray technology to analyze uterine fluid, but it has not been developed into clinical diagnostic test.

Here, the aim of our study was to investigate the feasibility of predicting ER with biomarkers from uterine fluid, and to establish a non-invasive RNA-seq based endometrium receptivity test (nirsERT) which has the potential to be used in reproductive clinic.

\section{Methods}

\section{Study Design}

The main objective of this study was to establish a prediction tool for endometrial receptivity using transcriptome sequencing data, and to evaluate the feasibility of non-invasive endometrial receptivity test using uterine fluid specimen. Firstly, from November 2017 to December 2018, participants were recruited to identify differentially expressed genes (DEGs) among pre-receptive, receptive and post-receptive endometrium by transcriptome sequencing and expression profile analysis and to build the nirsERT model appling machine

102 learning algorithm of random forest (RF). To limit interference from confounding variables affecting ER, the

103 inclusion criteria for IVF patients were as follows: 20-39 years of age; body mass index (BMI)=18-25 kg/m2;

104 secondary infertility with a history of a intrauterine pregnancy/pregnancies and undergoing the first IVF cycle

105 due to tubal factors; primary infertility undergoing the first IVF cycle due to male factors; a regular menstrual cycle length (25-35 days) with spontaneous ovulation; normal ovarian reserve (baseline FSH $<10 \mathrm{mIU} / \mathrm{mL}$, antimullerian hormone $>1.5 \mathrm{ng} / \mathrm{ml}$, antral follicle count $>5$ ); able to be followed up to assess the pregnancy outcome, and successful intrauterine pregnancy after the first embryo transfer (ET). The intrauterine pregnancy was defined as the presence of a gestational sac with or without fetal heart activity in the uterine cavity as evaluated by ultrasound 4-5 weeks after ET. To establish the prediction tool, normal ER status was defined 111 with successful intrauterine pregnancy.

112 Secondly, from January to April 2019, participants were recruited to demonstrate the accuracy of nirsERT

113 in predicting WOI. The inclusion criteria for patients who collected uterine fluid on the day of blastocysts

114 transfer were as follows: 20-39 years of age; BMI $=18-25 \mathrm{~kg} / \mathrm{m}^{2}$; ultrasound showed endometrial thickness $\geq$ $1158 \mathrm{~cm}$ and endogenous serum progesterone level $\leq 1.2 \mathrm{ng} / \mathrm{ml}$ on the day of progesterone administration/LH peak; 116 the transferred embryos were high-quality blastocysts (blastocysts $\geq 3$ BB on Day 5 and Day 6, graded based 117 on the Gardner system) [27]. 
medRxiv preprint doi: https://doi.org/10.1101/2021.03.07.21253097; this version posted March 9, 2021. The copyright holder for this preprint (which was not certified by peer review) is the author/funder, who has granted medRxiv a license to display the preprint in perpetuity.

All rights reserved. No reuse allowed without permission.

The following exclusion criteria were applied: endometrial diseases (including intrauterine adhesions, endometrial polyps, endometritis, endometrial tuberculosis, endometrial hyperplasia, and a thin endometrium); hydrosalpinx without proximal tubal ligation; submucous myomas, intramural hysteromyomas, or adenomyomas protruding towards the uterine cavity; endometriosis (stages III-IV); uterine malformations; and other medical or surgical co-morbidities were identified by consulting medical records, physical examination, blood test, B-ultrasound and X-ray examination.

In the validation group, all patients were performed nirsERT and were followed up to 4-5 weeks after ET to determine intrauterine pregnancy by ultrasound.

\section{Ethics statement} registered with the Chinese Clinical Trial Registry (No. ChiCTR-DDD-17013375).

\section{Uterine fluid collection, processing and transcriptome sequencing}

All patients signed the written informed consent before sample collection. For patients included in the model construction, ultrasound was initiated from day 10 of the menstrual cycle preceding the IVF cycle to monitor ovulation. Blood LH levels were dynamically measured daily when the follicle diameter was $>14 \mathrm{~mm}$.

134 Patients continue to undergo daily ultrasound monitoring of ovulation until follicular discharge. Uterine fluid 135 were respectively collected using embryo transfer catheter (Cook Medical; America) on days 5, 7, and 9

136 ( $\mathrm{LH}+5, \mathrm{LH}+7$, and $\mathrm{LH}+9$, respectively) after the $\mathrm{LH}$ surge (denoted as LH+0). For patients in the model 137 validation group, the uterine fluid was collected on the day of blastocyst transfer before embryo transfer.

138 (Transfers of frozen-thawed blastocysts were performed on the 7 days after the LH surge of natural cycle / the 1395 days after progesterone supplementation of hormone replacement (HRT) cycles).

The sampling was performed as follows. The cervix was cleansed with saline before sampling. After the outer catheter of the embryo transfer catheter was inserted through the cervix to a depth of $4 \mathrm{~cm}$ from the external cervical os, the inner catheter was introduced into the uterine cavity to a point $1-2 \mathrm{~cm}$ from the uterine

143 fundus to avoid contamination with cervical mucus. A $2.5 \mathrm{~mL}$ syringe was connected to the inner catheter and

144 suction was applied. Inner catheter was withdrawn within the external catheter before external catheter was

145 withdrawn from the uterus. Approximately 5-10uL of uterine fluid obtained were immediately placed into 20

146 uL of RNA-later buffer (AM7020; Thermo Fisher Scientific, Waltham, MA, USA) for RNA stabilization,

147 sealed, and cryopreserved at $-20^{\circ} \mathrm{C}$. Sequencing analysis was carried out within 7 days after sampling. 
and library preparation were conducted using the MALBAC ${ }^{\circledR}$ Platinum single cell RNA amplification kit and Transposon library Prep kit (KT110700796, and XY045, Yikon Genomics, Suzhou, China). Qualified libraries were sequenced by using the Illumina HiSeq 2500 platform with single-end reads length of $140 \mathrm{bp}$. An average number of 5 million reads was generated for each library. identified by analysis of variance (ANOVA). The equation is stated as follows:

$$
Y_{g i j k}=\mu_{g}+T_{g i}+S_{g j}+\varepsilon_{g i j k}
$$

where $\mu_{g}$ represents the mean expression level of gene $\mathrm{g} ; T_{g i}$ is gene-specific treatment effect referring to the status of being natural cycle or a hormone replacement therapy when uterine fluid was obtained, $T_{g i} \sim\left(0, \sigma_{T_{g}}^{2}\right)$; $S_{g j}$ is gene-specific endometrial receptivity stage effect with three levels (pre-receptivity, receptivity, and post-

receptivity), $S_{g i} \sim\left(0, \sigma_{S_{g}}^{2}\right)$; and $\varepsilon_{g i j k}$ is gene-dependent residual error, $\varepsilon_{g i j k} \sim\left(0, \sigma_{\varepsilon_{g}}^{2}\right)$. The F-test was applied to statistically assess the equality of variances between $S_{j}$ and $\varepsilon_{i j k}$ for each gene, showing whether the gene is differentially expressed among different endometrial receptivity stages. Because RNA-Seq analysis involves multiple statistical tests, the false discovery rate (FDR) was used to adjust the p-value (q-value) to provide statistical inference.

\section{Co-expression network construction and visualization}

Co-expression modules in the endometrial receptivity process were detected by weighted gene coexpression network analysis (WGCAN) [28]. Applying WGCNA, we then identified key modules significantly correlated with endometrial receptivity stages. Cytoscape software was then used to visualize the interaction networks with different co-expression key modules [29].

\section{Biomarker identification and performance validation}

To identify biomarkers for predictive model construction, post-hoc Tukey HSD (Honestly Significant

174 with significant differences of all pairwise test were detected for maximally distinguishing each receptive stage.

175 Expression values of these biomarkers were then inputted as features for the machine learning method-random

176 forest to train the pattern on three ER conditions (pre-receptivity, receptivity, and post-receptivity). The top

177 important features (gene expression) were further selected by R package random Forest based on two measures

178 (mean decrease accuracy and mean decrease gini). Out-of-bag (OOB) error, mean accuracy, sensitivity,

179 specificity, positive predictive value, negative predictive value and F1 were determined from 10-fold cross-

180 validation.

\section{Statistical analysis}


medRxiv preprint doi: https://doi.org/10.1101/2021.03.07.21253097; this version posted March 9, 2021. The copyright holder for this preprint (which was not certified by peer review) is the author/funder, who has granted medRxiv a license to display the preprint in perpetuity.

All rights reserved. No reuse allowed without permission.

Continuous data subject to a normal distribution were expressed as the mean $\pm \mathrm{SD}$. Continuous data subject to a skewed distribution were expressed as the median and inter-quartile range (IQR). Categorical data were expressed as counts and percentages, and were determined to be statistically significant using the chisquare test or Fisher's exact test. A two-side P-value equal or less than 0.05 was considered to be statistically significant. Statistical analysis was performed using IBM SPSS software (Version 23.0, IBM Corp.)

\section{Results}

\section{Participants}

To establish the nirsERT model, we collected uterine fluid of three different receptive stages (prereceptive, receptive and post-receptive) from infertile patients with normal WOI timing for RNA-seq. 69 participants were recruited and 21 patients who were not pregnant after the first embryo transfer were excluded, and 48 patients with successful intrauterine pregnancies were used to build nirsERT model (Figure 1). Baseline clinical characteristics are shown in supplementary Table S1.

\section{Uterine fluid RNA extraction and sequencing}

To perform the transcriptome sequencing, we collected 144 uterine fluid specimens from 48 participants and extracted total RNA by using commercial kit. As expected, the yield of RNA was relative low, ranging from 0 to 1160ng, with an average of 148ng. Almost one third of RNA samples were below detection limit of Qubit RNA HS assay kit $(0.25 \mathrm{ng} / \mu \mathrm{L})$. Normally, it's difficult to construct sequencing libraries starting with less than 1ng of total RNA. To address this, we utilized a commercial kit for reverse transcription and amplification with low amount of RNA.

We first validated the repeatability of transcriptome sequencing combined with above-mentioned kit (see supplementary methods). The Spearman correlation between different initial amounts of RNA was above 0.95 , showing a high stability and repeatability of this method with at least 0.2 ng RNA (Supplementary Figure S1). Then, we processed the 144 RNA samples according to the same protocol. As result, 140 NGS libraries were successfully constructed and sequenced, generating an average of 5.5 million raw reads per library. 632 million of high-quality reads, representing approximately $82.1 \%$ of raw data, were mapped to the human reference genome (Hg19). The number of mapped genes ranged from 9,591 to 17,913 in each library.

\section{DEGs detection and functional analysis}

To identify differentially expressed genes (DEGs) among pre-receptivity, receptivity, and postreceptivity stages, ANOVA (analysis of variance) was applied to process the $\log 2$ transformed transcriptomic data. As result, 864 DEGs were detected within three different ER status. Notably, there are relatively more down-regulated DEGs between post-receptivity and receptivity status (Figure 2A). Unsupervised hierarchical clustering of the DEGs showed three distinct groups. GO analysis of these DEGs were conducted by DAVID 
medRxiv preprint doi: https://doi.org/10.1101/2021.03.07.21253097; this version posted March 9, 2021. The copyright holder for this preprint (which was not certified by peer review) is the author/funder, who has granted medRxiv a license to display the preprint in perpetuity.

All rights reserved. No reuse allowed without permission.

tool (20). The DEGs were significantly enriched in 71 biological process (BP) terms, 38 cellular component (CC) terms and 25 molecular function (MF) terms. The top 1 enriched term for each category are signal transduction (GO:0007165), cytoplasm (GO:0005737), and protein binding (GO:0005515), respectively (Table 1 and Figure 2B).

To further investigate the functional module of DEGs in uterine fluid samples, we used the weighted gene co-expression network analysis (WGCNA) algorithm to analyze transcription regulatory networks. As result, 4 co-expression network modules with 3 being highly significant correlation with ER stages, which are MEturquoise, MEyellow and MEblue modules. Four hub genes ECI2 (MEturquoise), ATP6V1B2 (MEyellow), CXCL16 (MEblue) and SELP (MEgrey) were then identified based on the highest intramodular connectivity in four co-expression modules (Table 2). The MEturquoise module includes the most of DEGs, representing 59.1\% (511/864) of total DEGs. It also shows the most significant correlation with ER stages with the correlation value of -0.7. Functional enrichment analysis shows genes in MEturquoise module involve in transcription regulation like epigenic modification related pathway; MEblue genes are enriched in GTPase mediated signal transduction, while MEyellow genes play roles in biomacromolecule transporting and cell-cell adherens junction. The result represents the whole involvement in endometrium-embryo crosstalk related biological processes of these DEGs detected in uterine fluid, which includes cell-cell communication, signal reception and transduction, and a series of cellular responses like transcription and translation of proteins responsible for embryo implantation.

\section{Establishing and validating the ER predictive tool}

With Tukey test from ANOVA analysis, we selected genes with different expression in each pairwise comparisons of receptive stages (pre-receptivity versus receptivity, receptivity versus post-receptivity, and prereceptivity versus post-receptivity). We therefore applied the expression pattern of these DEGs as training features for ER status classification using the random forest method. The random forest-based feature importance analysis with a top contribution to the model prediction by the mean decrease accuracy and Gini index was performed (21), resulting 87 predictive markers (Table 3). To strengthen the power of the predictive tool, we include three hub genes as additional markers (Figure 3), resulting the nirsERT. Linear discriminant analysis (LDA) showed three ER conditions (pre-receptivity, receptivity, and post-receptivity) were distinctly

242 classified by the expression pattern of these transcriptomic markers (Figure 4A). To assess the performances of

243 the present predictor, a 10-fold cross-validation was applied. We got mean accuracy of $93.0 \%$, mean

244 specificity of $95.9 \%$, mean sensitivity of $90.0 \%$. Uterine fluid samples of different ER conditions could be well

245 separated by setting as a probability threshold of 0.6 (Figure 4B).

\section{Retrospective observation of a small cohort of patients undergoing IVF}

To further evaluate the accuracy of the nirsERT, we analyzed the correlation between the predicted results of nirsERT and pregnancy outcomes. 22 uterine fluid samples from IVF patients were collected on the 
medRxiv preprint doi: https://doi.org/10.1101/2021.03.07.21253097; this version posted March 9, 2021. The copyright holder for this preprint (which was not certified by peer review) is the author/funder, who has granted medRxiv a license to display the preprint in perpetuity.

All rights reserved. No reuse allowed without permission.

day of blastocyst transfer before embryo transfer and tested. The intrauterine pregnancy was determined by ultrasound 28 days after embryos transferred. The success rate of sequencing was $95.4 \%$ (21/22), with 1 libraries failed to pass the quality control procedure. As result, 18 patients $(85.7 \%, 18 / 21)$ were predicted with normal WOI, whereas $3(14.3 \%, 3 / 21)$ and 0 were predicted with delayed and advanced WOI, respectively. The intrauterine pregnancy rate (IPR) was 77.8\% (14/18) among patients with normal WOI. There was no successful pregnancy in patients with displaced WOI, which was significantly different from those with normal WOI $(P<0.05)$. The overall IPR in all patients was 63.6\% $(14 / 22)$ (Table 4$)$.

\section{Discussion}

In the past decades, researchers have investigated a variety of approaches to evaluate the condition of endometrial receptivity. However, limited progress had been made until the transcriptomic markers were established [26, 30]. Diagnostic tool result from endometrial tissue transcriptome is accurate and reproducible, but the application was also hindered by the necessity of invasive sampling. Thus, developing a non-invasive, precise and reliable method of ERT is one of the major challenges in reproductive medicine. In this study, a non-invasive ERT method based on RNA-seq was described for the first time, and it had the following benefits compared with previous studies: (1) RNA-seq could be used to identify more genes and in a more accurate manner than the conventional gene microarray; (2) Rather than two time points sampling, we collected samples of uterine fluid at three different time points, the pre-receptive, receptive, and post-receptive. Thus, the time span was shorten and a highly correlated sample cohort was established; (3) over 800 of DEGs in uterine fluid were analyzed, providing insight into function and role of multiple genes in the process of embryo implantation. It is difficult to perform transcriptome sequencing with uterine fluid samples, as nearly $1 / 3$ of the samples yielded total RNA less than $0.25 \mathrm{ng} / \mu \mathrm{L}$. To address this, we utilized a commercial kit designed for single-cell RNA reverse transcription and amplification. The results showed a high stability and repeatability, the Spearman correlation between different amounts of total RNA ranging from 0.2ng to 20ng were above 0.98. By using this kit, we successfully prepared 140 RNA-seq libraries and constructed the training dataset. However, there were still 4 libraries failed to pass the quality control, we assume this might be caused by extremely low amount of RNA in these uterine fluid samples. To ensure the availability of nirsERT, it is important to investigate the distribution of the amount of total RNA in population. Besides, the improvement of uterine fluid aspiration could be helpful in further studies.

According to our previous study (preprinted) [31], there were 3571 DEGs identified from endometrial tissue among there ER status, a predictive tool (rsERT) consisted of 175 marker genes was established based on these DEGs. In current, a total of 864 DEGs were identified, including 468 common DEGs and 396 uterine fluid specific DEGs, compared with the study of rsERT. We found these common DEGs are significantly enriched in extracellular exosome (GO:0070062), cytoplasm (GO:0005737), cytosol (GO:0005829), 
medRxiv preprint doi: https://doi.org/10.1101/2021.03.07.21253097; this version posted March 9, 2021. The copyright holder for this preprint (which was not certified by peer review) is the author/funder, who has granted medRxiv a license to display the preprint in perpetuity.

All rights reserved. No reuse allowed without permission.

nucleoplasm (GO:0005654) and protein binding (GO:0005515), which support the scenario that RNAs in uterine fluid originated from endometrial tissue cell with exosome secreted the outside of the cell. Unexpectedly, 396 DEGs were specifically observed in uterine fluid samples. These genes significantly involve in integrin-mediated signaling pathway (GO:0007229) and immune responses like leukocyte migration (GO:0050900), inflammatory response (GO:0006954) and response to lipopolysaccharide (GO:0032496). Besides, approximately $38.2 \%$ (330 of 864) of total DEGs were previously reported [13, 14, 32-35], while 61.8\% (534 of 864) were first identified to be differently expressed in all three status of receptive. Our findings highlight the importance of genes involved in protein binding, signal transduction, and leukocyte migration in the uterine fluid. For instance, DEGs enriched in extracellular exosome (GO:0070062), including SLC25A1 (ENSG00000100075), PLSCR1 (ENSG00000188313), and NME3 (ENSG00000103024) were observed to be significantly related to the dynamic change of the sequential receptivity stages, which are assumed to mediate the communication between endometrium and embryo. Other cellular responses and signal transductionrelated factors, e.g., RAC2 (ENSG00000128340) and ESR1 (ENSG00000091831), were also observed in our study (see Supplementary Table S2 and S3).

Four hub genes, ECI2, ATP6V1B2, CXCL16 and SELP were identified by using WGCNA analysis. ECI2 encodes a key mitochondrial enzyme involved in beta-oxidation of unsaturated fatty acids which may provide energy necessary for embryo implantation course. SELP implies the possible mechanism of P-selectin mediated cell adhesion in endometrium-embryo interaction. CXCL16 and its receptor CXCR6 were reported to play role in the decidualization during pregnancy [36]. ATP6V1B2 (ATPase H+ Transporting V1 Subunit B2) is a transmembrane transporter, which may be responsible for transporting biomacromolecule like secretory protein to its target location like extracellular matrix.

nirsERT consisting of 87 markers and 3 hub genes were selected by using random forest algorithm among 864 DEGs was established. We compared two predictive tools, nirsERT and rsERT established by using endometrial tissue samples in our previous study, only 22 markers were shared for both uterine fluid and tissue samples (Supplementary Table S4). According to the Human Protein Atlas, proteins generated by these gene locate in variety of subcellular locations [24], such as vesicle (BAG5, RAMP2), nucleus or nucleoplasm (ZNF652, TRAK1), cytosol (MAP2K6, RNF125) and cell junctions (PKP2). Besides, High correlation of

312 endometrial cells or extracellular vesicles. The performance of nirsERT with rsERT was also compared study

313 by using a same standard. 10-fold cross-validation resulted in comparable mean accuracy (93.0\% vs $98.4 \%$ ),

314 mean specificity (95.9\% vs $98.9 \%$ ) and mean sensitivity ( $90 \%$ vs $97.8 \%$ ).

We also investigated the selected markers in previous studies [14, 26], poor commonness was observed 316 (Supplementary Figure S3). No common marker is selected in all three studies. There is no universal standard 317 of selecting marker genes for endometrial receptivity, the mechanism of uterine transcriptomic changes during 
medRxiv preprint doi: https://doi.org/10.1101/2021.03.07.21253097; this version posted March 9, 2021. The copyright holder for this preprint (which was not certified by peer review) is the author/funder, who has granted medRxiv a license to display the preprint in perpetuity.

All rights reserved. No reuse allowed without permission.

the process of embryo implantation is still unrevealed. Further investigations are required for raising power and reproducibility of the endometrial receptivity prediction.

To verify the accuracy of nirsERT in predicting endometrial receptivity, the uterine fluid collected on the day of blastocyst transfer was performed nirsERT. The accuracy of nirsERT prediction was evaluated by analyzing the correlation between the predicted results and subsequent pregnancy outcomes. The results showed that $77.8 \%$ (14/18) of patients predicted with normal WOI had successful intrauterine pregnancies, while none of the 3 patients with displaced WOI had successful pregnancy. It is suggested that the failure of embryo implantation in patients with displaced WOI may be the result of embryo-endometrial asynchrony. Although there are still four unsuccessful intrauterine pregnancies in patients with normal WOI predicted by nirsERT, $77.8 \%$ of IRP is consistent with the view that endometrial factors are responsible for about two-thirds of embryo implantation $[37,38]$. Therefore, the results also further clinically validated the accuracy of nirsERT in predicting WOI. Personalized embryo transfer ( $\mathrm{pET}$ ) guided by nirsERT can possibly contribute to restore the synchronicity of embryonic and endometrial development which promoted successful embryo implantation. In addition, clinical pregnancy rate of routine blastocyst transplantation in our center was 55$60 \%$, while the overall intrauterine pregnancy rate of patients with aspiration of uterine fluid on the day of embryo transfer was $63.6 \%$, suggesting that aspiration of uterine fluid did not affect the embryo implantation. nirsERT has the potential to detect and guide pET in a same active cycle contributing to the successful embryo implantation.

It follows that our method provides currently the most promising approach for ideal $\mathrm{pET}$. However, there is an issue has to confront, which is that whether nirsERT can improve the pregnancy outcomes of IVF patients by guiding pET has not been demonstrated yet, and we think it would be better to design a randomized clinical trial in the future to verify the clinical application value of nirsERT. In addition, the mechanism of endometrial receptivity marker genes also needs further investigation so as to provide theoretical basis for clinical treatment strategy.

\section{Conclusions}

344 In conclusion, we established a non-invasive RNA-seq based endometrial receptivity test (nirsERT) by

345 transcriptome sequencing analysis of uterine fluid combined with random forest algorithm. Endometrial

346 receptive DEGs in uterine fluid may be derived from endometrial tissue cells and have an independent role in

347 embryo implantation. nirsERT has the equivalent accuracy of endometrial receptive prediction to endometrium

348 samples and is potential for a non-invasive, accurate and same cycle testing for endometrium receptivity in

349 reproductive clinic. 
medRxiv preprint doi: https://doi.org/10.1101/2021.03.07.21253097; this version posted March 9, 2021. The copyright holder for this preprint (which was not certified by peer review) is the author/funder, who has granted medRxiv a license to display the preprint in perpetuity.

All rights reserved. No reuse allowed without permission.

Acknowledgments

353

We thank all patients and their family for the participation. We also thank Elsevier Author Services for preparation the Figure 3.

\section{Conflict of Interest}

All the authors have read the manuscript and approved this for submission as well as no competing interests.

\section{References}

1. Macklon NS, Stouffer RL, Giudice LC, Fauser BC: The science behind 25 years of

2. Simon A, Laufer N: Repeated implantation failure: clinical approach. Fertil Steril 2012, 97:1039-1043.

3. Prapas Y, Prapas N, Jones EE, Duleba AJ, Olive DL, Chatziparasidou A, Vlassis G: The window for embryo transfer in oocyte donation cycles depends on the duration of progesterone therapy. Hum Reprod 1998, 13:720-723.

4. Norwitz ER, Schust DJ, Fisher SJ: Implantation and the survival of early pregnancy. N Engl J Med 2001, 345:1400-1408.

5. Galliano D, Bellver J, Díaz-García C, Simón C, Pellicer A: ART and uterine pathology: how relevant is the maternal side for implantation? Hum Reprod Update 2015, 21:1338 .

6. Sebastian-Leon P, Garrido N, Remohí J, Pellicer A, Diaz-Gimeno P: Asynchronous and pathological windows of implantation: two causes of recurrent implantation failure. Hum Reprod 2018, 33:626-635.

7. Zhao J, Zhang Q, Wang Y, Li Y: Endometrial pattern, thickness and growth in predicting pregnancy outcome following 3319 IVF cycle. Reprod Biomed Online 2014, 29:291-298.

8. Zhao J, Zhang Q, Li Y: The effect of endometrial thickness and pattern measured by ultrasonography on pregnancy outcomes during IVF-ET cycles. Reprod Biol Endocrinol 2012, 10:100.

9. Hou Z, Zhang Q, Zhao J, Xu A, He A, Huang X, Xie S, Fu J, Xiao L, Li Y: Value of endometrial echo pattern transformation after hCG trigger in predicting IVF pregnancy outcome: a prospective cohort study. Reprod Biol Endocrinol 2019, 17:74.

10. Coutifaris C, Myers ER, Guzick DS, Diamond MP, Carson SA, Legro RS, McGovern PG, Schlaff WD, Carr BR, Steinkampf MP, et al: Histological dating of timed endometrial biopsy tissue is not related to fertility status. Fertil Steril 2004, 82:12641272.

11. Zhu L, Che HS, Xiao L, Li YP: Uterine peristalsis before embryo transfer affects the chance of clinical pregnancy in fresh and frozen-thawed embryo transfer cycles. Hum Reprod 2014, 29:1238-1243.

12. Qiong Z, Jie H, Yonggang W, Bin X, Jing Z, Yanping L: Clinical validation of pinopode as a marker of endometrial receptivity: a randomized controlled trial. Fertil Steril 
medRxiv preprint doi: https://doi.org/10.1101/2021.03.07.21253097; this version posted March 9, 2021. The copyright holder for this preprint (which was not certified by peer review) is the author/funder, who has granted medRxiv a license to display the preprint in perpetuity. All rights reserved. No reuse allowed without permission.

2017, 108:513-517 e512.

13. Hu S, Yao G, Wang Y, Xu H, Ji X, He Y, Zhu Q, Chen Z, Sun Y: Transcriptomic changes during the pre-receptive to receptive transition in human endometrium detected by RNA-Seq. J Clin Endocrinol Metab 2014, 99:E2744-2753.

14. Diaz-Gimeno P, Horcajadas JA, Martinez-Conejero JA, Esteban FJ, Alama P, Pellicer A, Simon C: A genomic diagnostic tool for human endometrial receptivity based on the transcriptomic signature. Fertil Steril 2011, 95:50-60, 60 e51-15.

15. Díaz-Gimeno P, Ruiz-Alonso M, Blesa D, Bosch N, Martínez-Conejero JA, Alamá P, Garrido N, Pellicer A, Simón C: The accuracy and reproducibility of the endometrial receptivity array is superior to histology as a diagnostic method for endometrial receptivity. Fertil Steril 2013, 99:508-517.

16. Garrido-Gómez T, Ruiz-Alonso M, Blesa D, Diaz-Gimeno P, Vilella F, Simón C: Profiling the gene signature of endometrial receptivity: clinical results. Fertil Steril 2013, 99:1078-1085.

17. Ruiz-Alonso M, Blesa D, Díaz-Gimeno P, Gómez E, Fernández-Sánchez M, Carranza F, Carrera J, Vilella F, Pellicer A, Simón C: The endometrial receptivity array for diagnosis and personalized embryo transfer as a treatment for patients with repeated implantation failure. Fertil Steril 2013, 100:818-824.

18. Simón C GC, Cabanillas S, Vladimirov I, Castillón G, Giles J, Boynukalin K, Findikli N, Bahçeci M, Ortega I, Vidal C, Funabiki M, Izquierdo A, López L, Portela S, Frantz N, Kulmann M, Taguchi S, Labarta E, Colucci F, Mackens S, Santamaría X, Muñoz E, Barrera S, García-Velasco JA, Fernández M, Ferrando M, Ruiz M, Mol BW, Valbuena D; ERA-RCT Study Consortium Group.: A 5-year multicentre randomized controlled trial comparing personalized, frozen and fresh blastocyst transfer in IVF. Reprod Biomed Online 2020, 41:14.

19. Nagalakshmi U, Waern K, Snyder M: RNA-Seq: a method for comprehensive transcriptome analysis. Curr Protoc Mol Biol 2010, Chapter 4:Unit 4.11.11-13.

20. Sîrbu A, Kerr G, Crane M, Ruskin HJ: RNA-Seq vs dual- and single-channel microarray data: sensitivity analysis for differential expression and clustering. PLoS One 2012, 7:e50986.

21. Kalma Y, Granot I, Gnainsky Y, Or Y, Czernobilsky B, Dekel N, Barash A: Endometrial biopsy-induced gene modulation: first evidence for the expression of bladdertransmembranal uroplakin Ib in human endometrium. Fertil Steril 2009, 91:10421049, 1049.e1041-1049.

22. Karimzade MA, Oskouian H, Ahmadi S, Oskouian L: Local injury to the endometrium on the day of oocyte retrieval has a negative impact on implantation in assisted reproductive cycles: a randomized controlled trial. Arch Gynecol Obstet 2010, 281:499-503.

23. Bhusane K, Bhutada S, Chaudhari U, Savardekar L, Katkam R, Sachdeva G: Secrets of Endometrial Receptivity: Some Are Hidden in Uterine Secretome. Am J Reprod Immunol 2016, 75:226-236.

24. Thul PJ, Åkesson L, Wiking M, Mahdessian D, Geladaki A, Ait Blal H, Alm T, Asplund A, Björk L, Breckels LM, et al: A subcellular map of the human proteome. Science $2017,356$.

25. van der Gaast MH, Beier-Hellwig K, Fauser BC, Beier HM, Macklon NS: Endometrial secretion aspiration prior to embryo transfer does not reduce implantation rates. 
medRxiv preprint doi: https://doi.org/10.1101/2021.03.07.21253097; this version posted March 9, 2021. The copyright holder for this preprint (which was not certified by peer review) is the author/funder, who has granted medRxiv a license to display the preprint in perpetuity. All rights reserved. No reuse allowed without permission.

Reprod Biomed Online 2003, 7:105-109.

26. Chan C, Virtanen C, Winegarden NA, Colgan TJ, Brown TJ, Greenblatt EM: Discovery of biomarkers of endometrial receptivity through a minimally invasive approach: a validation study with implications for assisted reproduction. Fertil Steril 2013, 100:810-817.

27. Gardner DK, Lane M, Stevens J, Schlenker T, Schoolcraft WB: Reprint of: Blastocyst score affects implantation and pregnancy outcome: towards a single blastocyst transfer. Fertil Steril 2019, 112:e81-e84.

28. Zhang B, Horvath S: A general framework for weighted gene co-expression network analysis. Stat Appl Genet Mol Biol 2005, 4:Article17.

29. Shannon P, Markiel A, Ozier O, Baliga NS, Wang JT, Ramage D, Amin N, Schwikowski B, Ideker T: Cytoscape: a software environment for integrated models of biomolecular interaction networks. Genome Res 2003, 13:2498-2504.

30. Suhorutshenko M, Kukushkina V, Velthut-Meikas A, Altmäe S, Peters M, Mägi R, Krjutškov K, Koel M, Codoñer FM, Martinez-Blanch JF, et al: Endometrial receptivity revisited: endometrial transcriptome adjusted for tissue cellular heterogeneity. Hum Reprod 2018, 33:2074-2086.

31. Aihua H, Yangyun Z, Cheng W, Jing Z, Qiong Z, Zhongyuan Y, Fen T, Hong W, Xi H, Jing F, et al: The Role of Transcriptomic Biomarkers of Endometrial Receptivity in Personalized Embryo Transfer for Patients with Repeated Implantation Failure. PREPRINT available at Research Square; DOI: 1021203/rs3rs-126797/v1 2020.

32. Kao LC, Tulac S, Lobo S, Imani B, Yang JP, Germeyer A, Osteen K, Taylor RN, Lessey BA, Giudice LC: Global gene profiling in human endometrium during the window of implantation. Endocrinology 2002, 143:2119-2138.

33. Borthwick JM, Charnock-Jones DS, Tom BD, Hull ML, Teirney R, Phillips SC, Smith SK: Determination of the transcript profile of human endometrium. Mol Hum Reprod 2003, 9:19-33.

34. Altmäe S, Reimand J, Hovatta O, Zhang P, Kere J, Laisk T, Saare M, Peters M, Vilo J, Stavreus-Evers A, Salumets A: Research resource: interactome of human embryo implantation: identification of gene expression pathways, regulation, and integrated regulatory networks. Mol Endocrinol 2012, 26:203-217.

35. Altmäe S, Koel M, Võsa U, Adler P, Suhorutšenko M, Laisk-Podar T, Kukushkina V, Saare M, Velthut-Meikas A, Krjutškov K, et al: Meta-signature of human endometrial receptivity: a meta-analysis and validation study of transcriptomic biomarkers. Sci Rep 2017, 7:10077.

36. Mei J, Yan Y, Li SY, Zhou WJ, Zhang Q, Li MQ, Sun HX: CXCL16/CXCR6 interaction promotes endometrial decidualization via the PI3K/AKT pathway. Reproduction 2019, 157:273-282.

37. Messaoudi S, El Kasmi I, Bourdiec A, Crespo K, Bissonnette L, Le Saint C, Bissonnette F, Kadoch IJ: 15 years of transcriptomic analysis on endometrial receptivity: what have we learnt? Fertil Res Pract 2019, 5:9.

38. Craciunas L, Gallos I, Chu J, Bourne T, Quenby S, Brosens JJ, Coomarasamy A: Conventional and modern markers of endometrial receptivity: a systematic review and meta-analysis. Hum Reprod Update 2019, 25:202-223. 
medRxiv preprint doi: https://doi.org/10.1101/2021.03.07.21253097; this version posted March 9, 2021. The copyright holder for this preprint (which was not certified by peer review) is the author/funder, who has granted medRxiv a license to display the preprint in perpetuity. All rights reserved. No reuse allowed without permission.

Table 1. GO enrichment analysis of DEGs from uterine fluid samples.

\begin{tabular}{|c|c|c|c|c|c|}
\hline Category & Term & Gene count & p-value & $\begin{array}{c}\text { Fold } \\
\text { Enrichment }\end{array}$ & FDR \\
\hline \multirow{10}{*}{$\begin{array}{l}\text { Biological } \\
\text { Process }\end{array}$} & GO:0007165 signal transduction & 83 & 2.92E-05 & 1.59 & 0.05 \\
\hline & $\begin{array}{l}\text { GO:0045944 positive regulation of } \\
\text { transcription from RNA polymerase II } \\
\text { promoter }\end{array}$ & 60 & $1.40 \mathrm{E}-02$ & 1.36 & 22.49 \\
\hline & $\begin{array}{l}\text { GO:0000122 negative regulation of } \\
\text { transcription from RNA polymerase II } \\
\text { promoter }\end{array}$ & 50 & $2.60 \mathrm{E}-03$ & 1.54 & 4.61 \\
\hline & $\begin{array}{l}\text { GO:0045893 positive regulation of } \\
\text { transcription, DNA-templated }\end{array}$ & 39 & $1.98 \mathrm{E}-03$ & 1.68 & 3.53 \\
\hline & $\begin{array}{l}\text { GO:0006357 regulation of transcription } \\
\text { from RNA polymerase II promoter }\end{array}$ & 36 & $8.56 \mathrm{E}-04$ & 1.81 & 1.54 \\
\hline & GO:0006954 inflammatory response & 26 & $3.67 \mathrm{E}-02$ & 1.52 & 49.24 \\
\hline & $\begin{array}{l}\text { GO:0043065 positive regulation of } \\
\text { apoptotic process }\end{array}$ & 24 & $9.19 \mathrm{E}-03$ & 1.77 & 15.42 \\
\hline & GO:0050900 leukocyte migration & 21 & $5.05 \mathrm{E}-07$ & 3.82 & 0.00 \\
\hline & GO:0001525 angiogenesis & 21 & $2.68 \mathrm{E}-03$ & 2.09 & 4.75 \\
\hline & GO:0008360 regulation of cell shape & 18 & $1.87 \mathrm{E}-04$ & 2.85 & 0.34 \\
\hline \multirow{10}{*}{$\begin{array}{l}\text { Cellular } \\
\text { Component }\end{array}$} & GO:0005737 cytoplasm & 298 & 7.41E-08 & 1.30 & 0.00 \\
\hline & GO:0005634 nucleus & 270 & 8.01E-03 & 1.13 & 10.94 \\
\hline & GO:0005829 cytosol & 200 & 8.78E-07 & 1.37 & 0.00 \\
\hline & GO:0070062 extracellular exosome & 183 & $1.55 \mathrm{E}-08$ & 1.48 & 0.00 \\
\hline & GO:0005654 nucleoplasm & 157 & $5.89 \mathrm{E}-04$ & 1.28 & 0.85 \\
\hline & GO:0016020 membrane & 146 & $2.40 \mathrm{E}-07$ & 1.51 & 0.00 \\
\hline & GO:0005739 mitochondrion & 81 & $2.41 \mathrm{E}-03$ & 1.38 & 3.42 \\
\hline & GO:0005615 extracellular space & 75 & $2.61 \mathrm{E}-02$ & 1.27 & 31.66 \\
\hline & $\begin{array}{l}\text { GO:0048471 perinuclear region of } \\
\text { cytoplasm }\end{array}$ & 38 & 3.75E-02 & 1.39 & 42.34 \\
\hline & GO:0009986 cell surface & 34 & $3.70 \mathrm{E}-02$ & 1.43 & 41.92 \\
\hline \multirow{10}{*}{$\begin{array}{l}\text { Molecular } \\
\text { Function }\end{array}$} & GO:0005515 protein binding & 492 & $2.66 \mathrm{E}-12$ & 1.23 & 0.00 \\
\hline & GO:0044822 poly(A) RNA binding & 72 & $3.03 \mathrm{E}-03$ & 1.41 & 4.64 \\
\hline & GO:0008270 zinc ion binding & 66 & 4.84E-02 & 1.24 & 54.05 \\
\hline & $\begin{array}{l}\text { GO:0042803 protein homodimerization } \\
\text { activity }\end{array}$ & 46 & $2.32 \mathrm{E}-02$ & 1.39 & 30.79 \\
\hline & $\begin{array}{l}\text { GO:0043565 sequence-specific } \text { DNA } \\
\text { binding }\end{array}$ & 33 & 4.91E-02 & 1.40 & 54.63 \\
\hline & GO:0003682 chromatin binding & 32 & $1.88 \mathrm{E}-03$ & 1.80 & 2.90 \\
\hline & GO:0005102 receptor binding & 27 & $1.07 \mathrm{E}-02$ & 1.69 & 15.49 \\
\hline & GO:0003779 actin binding & 26 & $9.10 \mathrm{E}-04$ & 2.06 & 1.42 \\
\hline & GO:0008134 transcription factor binding & 26 & $1.23 \mathrm{E}-03$ & 2.02 & 1.90 \\
\hline & $\begin{array}{l}\text { GO:0044212 transcription } \\
\text { region DNA binding }\end{array}$ & 17 & $3.33 \mathrm{E}-02$ & 1.76 & 41.17 \\
\hline
\end{tabular}


medRxiv preprint doi: https://doi.org/10.1101/2021.03.07.21253097; this version posted March 9, 2021. The copyright holder for this preprint (which was not certified by peer review) is the author/funder, who has granted medRxiv a license to display the preprint in perpetuity.

All rights reserved. No reuse allowed without permission.

Table 2. WGCNA analysis of DEGs from uterine fluid.

\begin{tabular}{|c|c|c|c|c|c|c|}
\hline Module & $\begin{array}{l}\text { Number } \\
\text { of genes }\end{array}$ & Hub gene & $\begin{array}{c}\text { Module- } \\
\text { receptivity } \\
\text { relationships }\end{array}$ & DAVID cluster & $\begin{array}{l}\text { *p- } \\
\text { value }\end{array}$ & $\begin{array}{c}\text { Enrichment } \\
\text { score }\end{array}$ \\
\hline \multirow{3}{*}{$\begin{array}{c}\mathrm{ME} \\
\text { turquoise }\end{array}$} & \multirow{3}{*}{510} & \multirow{3}{*}{ ECI2 } & \multirow{3}{*}{-0.7} & GO:0016575 histone deacetylation & 0.0479 & \multirow{3}{*}{3.44} \\
\hline & & & & GO:0004407 histone deacetylase activity & 0.0371 & \\
\hline & & & & GO:0016581 NuRD complex & 0.0416 & \\
\hline \multirow{3}{*}{ ME blue } & \multirow{3}{*}{265} & \multirow{3}{*}{ CXCL16 } & \multirow{3}{*}{0.55} & $\begin{array}{l}\text { GO:0051056 regulation of small GTPase } \\
\text { mediated signal transduction }\end{array}$ & 0.0192 & \multirow{3}{*}{3.5} \\
\hline & & & & $\begin{array}{l}\text { GO:0043547 positive regulation of GTPase } \\
\text { activity }\end{array}$ & 0.0385 & \\
\hline & & & & GO:0005096 GTPase activator activity & 0.0557 & \\
\hline \multirow{3}{*}{ ME yellow } & \multirow{3}{*}{78} & \multirow{3}{*}{ ATP6V1B2 } & \multirow{3}{*}{0.69} & GO:0042470 melanosome & 0.0133 & \multirow{3}{*}{2.4} \\
\hline & & & & GO:0045121 membrane raft & 0.0935 & \\
\hline & & & & GO:0005913 cell-cell adherens junction & 0.0935 & \\
\hline
\end{tabular}

488 *: Benjamini adjusted p-value

489 
medRxiv preprint doi: https://doi.org/10.1101/2021.03.07.21253097; this version posted March 9, 2021. The copyright holder for this preprint (which was not certified by peer review) is the author/funder, who has granted medRxiv a license to display the preprint in perpetuity. All rights reserved. No reuse allowed without permission.

Table 3. List of predictive markers selected by random forest algorithm

\begin{tabular}{|c|c|c|c|}
\hline HGNC ID & $\begin{array}{l}\text { Approved } \\
\text { symbol }\end{array}$ & Approved name & $\begin{array}{l}\text { Mean } \\
\text { Decrease } \\
\text { Accuracy }\end{array}$ \\
\hline HGNC:9441 & PRKX & protein kinase $\mathrm{X}$-linked & 5.21 \\
\hline HGNC:8910 & PGR & progesterone receptor & 5.05 \\
\hline HGNC:29545 & SUDS3 & SDS3 homolog, SIN3A corepressor complex component & 4.95 \\
\hline HGNC:704 & ARPC1B & actin related protein $2 / 3$ complex subunit $1 \mathrm{~B}$ & 4.72 \\
\hline HGNC:12393 & TTC3 & tetratricopeptide repeat domain 3 & 4.69 \\
\hline HGNC:28149 & PRR15L & proline rich 15 like & 4.54 \\
\hline HGNC:7213 & MPHOSPH10 & M-phase phosphoprotein 10 & 4.53 \\
\hline HGNC:20313 & PKHD1L1 & PKHD1 like 1 & 4.51 \\
\hline HGNC:5157 & HPRT1 & hypoxanthine phosphoribosyltransferase 1 & 4.48 \\
\hline HGNC:17582 & KAT6B & lysine acetyltransferase $6 \mathrm{~B}$ & 4.48 \\
\hline HGNC:18196 & SOX7 & SRY-box transcription factor 7 & 4.41 \\
\hline HGNC:23785 & PIKFYVE & phosphoinositide kinase, FYVE-type zinc finger containing & 4.4 \\
\hline HGNC: 17814 & SLF2 & SMC5-SMC6 complex localization factor 2 & 4.36 \\
\hline HGNC: 11107 & SMARCD2 & $\begin{array}{l}\text { SWI/SNF related, matrix associated, actin dependent regulator of } \\
\text { chromatin, subfamily d, member } 2\end{array}$ & 4.35 \\
\hline HGNC:4461 & GPM6B & glycoprotein M6B & 4.33 \\
\hline HGNC: 2470 & CSRP2 & cysteine and glycine rich protein 2 & 4.31 \\
\hline HGNC: 18854 & CREB3L4 & cAMP responsive element binding protein 3 like 4 & 4.31 \\
\hline HGNC:11615 & TCEA3 & transcription elongation factor $\mathrm{A} 3$ & 4.28 \\
\hline HGNC: 17947 & THEM4 & thioesterase superfamily member 4 & 4.26 \\
\hline HGNC: 2567 & OFD1 & OFD1 centriole and centriolar satellite protein & 4.25 \\
\hline HGNC: 4330 & GLRX & glutaredoxin & 4.24 \\
\hline HGNC:24663 & RABGAP1L & RAB GTPase activating protein 1 like & 4.2 \\
\hline HGNC:17811 & AMOTL1 & angiomotin like 1 & 4.19 \\
\hline HGNC:4183 & GBP2 & guanylate binding protein 2 & 4.14 \\
\hline HGNC:26323 & ANKRD35 & ankyrin repeat domain 35 & 4.13 \\
\hline HGNC:14651 & PPIH & peptidylprolyl isomerase $\mathrm{H}$ & 4.11 \\
\hline HGNC:16462 & STRBP & spermatid perinuclear RNA binding protein & 4.08 \\
\hline HGNC: 17717 & STK39 & serine/threonine kinase 39 & 4.05 \\
\hline HGNC:25585 & OGFOD1 & 2-oxoglutarate and iron dependent oxygenase domain containing 1 & 4.04 \\
\hline HGNC:7784 & NFIA & nuclear factor I A & 4.02 \\
\hline HGNC:20340 & PRICKLE2 & prickle planar cell polarity protein 2 & 4 \\
\hline HGNC:9024 & PKP2 & plakophilin 2 & 3.99 \\
\hline HGNC:21923 & STEAP4 & STEAP4 metalloreductase & 3.94 \\
\hline HGNC:4171 & GATA2 & GATA binding protein 2 & 3.93 \\
\hline HGNC:21150 & RNF125 & ring finger protein 125 & 3.89 \\
\hline HGNC: 6846 & MAP2K6 & mitogen-activated protein kinase kinase 6 & 3.85 \\
\hline HGNC:411 & ALDH3B2 & aldehyde dehydrogenase 3 family member B2 & 3.85 \\
\hline HGNC: 19300 & STX19 & syntaxin 19 & 3.83 \\
\hline HGNC:4881 & HEY2 & hes related family bHLH transcription factor with YRPW motif 2 & 3.83 \\
\hline HGNC:18296 & PPP4R2 & protein phosphatase 4 regulatory subunit 2 & 3.82 \\
\hline
\end{tabular}




\begin{tabular}{|c|c|c|c|}
\hline HGNC:5464 & IGF1 & insulin like growth factor 1 & 3.81 \\
\hline HGNC:28990 & ZNF516 & zinc finger protein 516 & 3.8 \\
\hline HGNC:25569 & NKAPD1 & NKAP domain containing 1 & 3.78 \\
\hline HGNC:10524 & SALL1 & spalt like transcription factor 1 & 3.76 \\
\hline HGNC:25764 & RMI1 & RecQ mediated genome instability 1 & 3.75 \\
\hline HGNC: 17925 & TFCP2L1 & transcription factor $\mathrm{CP} 2$ like 1 & 3.74 \\
\hline HGNC:20814 & ZNF436 & zinc finger protein 436 & 3.74 \\
\hline HGNC:30447 & PLD6 & phospholipase D family member 6 & 3.74 \\
\hline HGNC:253 & ADH5 & alcohol dehydrogenase 5 (class III), chi polypeptide & 3.72 \\
\hline HGNC:24944 & DDIT4 & DNA damage inducible transcript 4 & 3.71 \\
\hline HGNC: 15513 & SMYD3 & SET and MYND domain containing 3 & 3.65 \\
\hline HGNC:29652 & WDR77 & WD repeat domain 77 & 3.61 \\
\hline HGNC:22201 & TCAF1 & TRPM8 channel associated factor 1 & 3.6 \\
\hline HGNC:8154 & OPRK1 & opioid receptor kappa 1 & 3.59 \\
\hline HGNC:8013 & HMGN5 & high mobility group nucleosome binding domain 5 & 3.58 \\
\hline HGNC: 18856 & CREB3L1 & cAMP responsive element binding protein 3 like 1 & 3.57 \\
\hline HGNC:28204 & NTPCR & nucleoside-triphosphatase, cancer-related & 3.57 \\
\hline HGNC: 18122 & SOX17 & SRY-box transcription factor 17 & 3.54 \\
\hline HGNC:20150 & RAB15 & RAB15, member RAS oncogene family & 3.52 \\
\hline HGNC:941 & BAG5 & BAG cochaperone 5 & 3.5 \\
\hline HGNC:7785 & NFIB & nuclear factor I B & 3.49 \\
\hline HGNC:9844 & RAMP2 & receptor activity modifying protein 2 & 3.48 \\
\hline HGNC:3821 & FOXO3 & forkhead box O3 & 3.46 \\
\hline HGNC:8995 & PIP5K1B & phosphatidylinositol-4-phosphate 5-kinase type 1 beta & 3.39 \\
\hline HGNC:33941 & SLC35E2B & solute carrier family 35 member E2B & 3.38 \\
\hline HGNC:4908 & $\mathrm{HIBCH}$ & 3-hydroxyisobutyryl-CoA hydrolase & 3.36 \\
\hline HGNC:5209 & HSD11B2 & hydroxysteroid 11-beta dehydrogenase 2 & 3.35 \\
\hline HGNC: 6813 & MAGED1 & MAGE family member D1 & 3.34 \\
\hline HGNC: 18757 & RHOBTB3 & Rho related BTB domain containing 3 & 3.32 \\
\hline HGNC:4253 & GGTA1 & glycoprotein alpha-galactosyltransferase 1 (inactive) & 3.32 \\
\hline HGNC:4254 & GGTA2P & glycoprotein alpha-galactosyltransferase 2 , pseudogene & 3.29 \\
\hline HGNC: 19990 & ANAPC4 & anaphase promoting complex subunit 4 & 3.24 \\
\hline HGNC:8062 & NUP153 & nucleoporin 153 & 3.23 \\
\hline HGNC: 12805 & $\mathrm{XDH}$ & xanthine dehydrogenase & 3.23 \\
\hline HGNC:23696 & TIPARP & TCDD inducible poly(ADP-ribose) polymerase & 3.22 \\
\hline HGNC:19391 & SOCS3 & suppressor of cytokine signaling 3 & 3.21 \\
\hline HGNC:29147 & ZNF652 & zinc finger protein 652 & 3.2 \\
\hline HGNC:29947 & TRAK1 & trafficking kinesin protein 1 & 3.18 \\
\hline HGNC: 13071 & PATZ1 & POZ/BTB and AT hook containing zinc finger 1 & 3.18 \\
\hline HGNC:1132 & BTG3 & BTG anti-proliferation factor 3 & 3.15 \\
\hline HGNC:30747 & COPS2 & COP9 signalosome subunit 2 & 3.13 \\
\hline HGNC:7541 & MXRA7 & matrix remodeling associated 7 & 3.13 \\
\hline HGNC:4403 & GNG11 & G protein subunit gamma 11 & 3.11 \\
\hline HGNC:31412 & SWI5 & SWI5 homologous recombination repair protein & 3.11 \\
\hline HGNC:16841 & LITAF & lipopolysaccharide induced TNF factor & 3.1 \\
\hline
\end{tabular}


medRxiv preprint doi: https://doi.org/10.1101/2021.03.07.21253097; this version posted March 9, 2021. The copyright holder for this preprint (which was not certified by peer review) is the author/funder, who has granted medRxiv a license to display the preprint in perpetuity.

All rights reserved. No reuse allowed without permission.

HGNC:7852 NME4 NME/NM23 nucleoside diphosphate kinase 4

491

492

493 
medRxiv preprint doi: https://doi.org/10.1101/2021.03.07.21253097; this version posted March 9, 2021. The copyright holder for this preprint (which was not certified by peer review) is the author/funder, who has granted medRxiv a license to display the preprint in perpetuity.

All rights reserved. No reuse allowed without permission.

Table 4. nirsERT results and clinical outcomes of 22 patients undergoing IVF.

\begin{tabular}{|c|c|c|c|c|c|c|}
\hline & Normal WOI & $\begin{array}{l}\text { Displa } \\
\text { delayed }\end{array}$ & $\begin{array}{l}\text { d WOI } \\
\text { advanced }\end{array}$ & $\begin{array}{c}P \text { - } \\
\text { value }\end{array}$ & $\begin{array}{l}\text { Detection } \\
\text { failed }\end{array}$ & Total \\
\hline Date of transfer & $\mathrm{LH}+7 / \mathrm{P}+5$ & $\mathrm{LH}+7 / \mathrm{P}+5$ & $\mathrm{LH}+7 / \mathrm{P}+5$ & & $\mathrm{LH}+7 / \mathrm{P}+5$ & \\
\hline Predicted result & Receptivity & Pre-receptivity & Post-receptivity & & l & \\
\hline No. of patients & 18 & 3 & 0 & & 1 & 22 \\
\hline No. of intrauterine pregnancy & 14 & 0 & 0 & & 0 & 14 \\
\hline Intrauterine pregnancy rate & $77.8 \%(14 / 18)$ & 0 & 0 & 0.026 & 0 & $63.6 \%(14 / 22)$ \\
\hline
\end{tabular}

495 
A

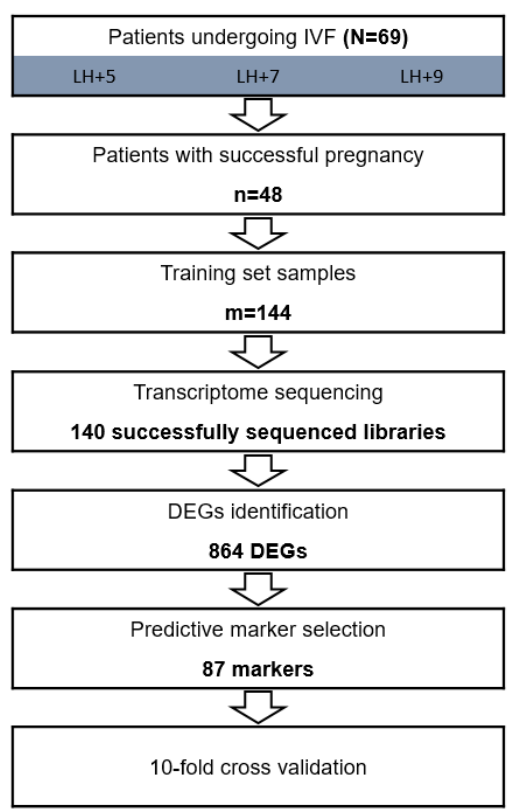

B

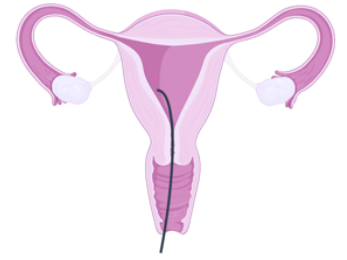

Uterine fluid aspiration

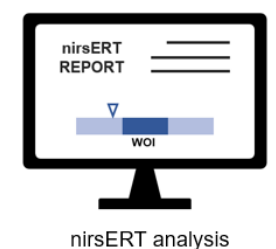

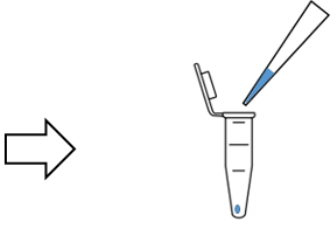

Low amount RNA RT and amplification

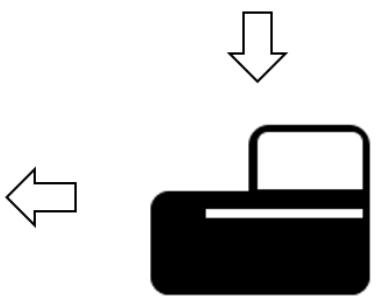

Library preparation and NGS sequencing

Figure. 1. Flow diagram of Establishing and application of the non-invasive RNA-seq based endometrial receptivity test. 
medRxiv preprint doi: https://doi.org/10.1101/2021.03.07.21253097; this version posted March 9, 2021. The copyright holder for this preprint (which was not certified by peer review) is the author/funder, who has granted medRxiv a license to display the preprint in perpetuity. All rights reserved. No reuse allowed without permission.

A

Re vs Pre

ost vs Pre
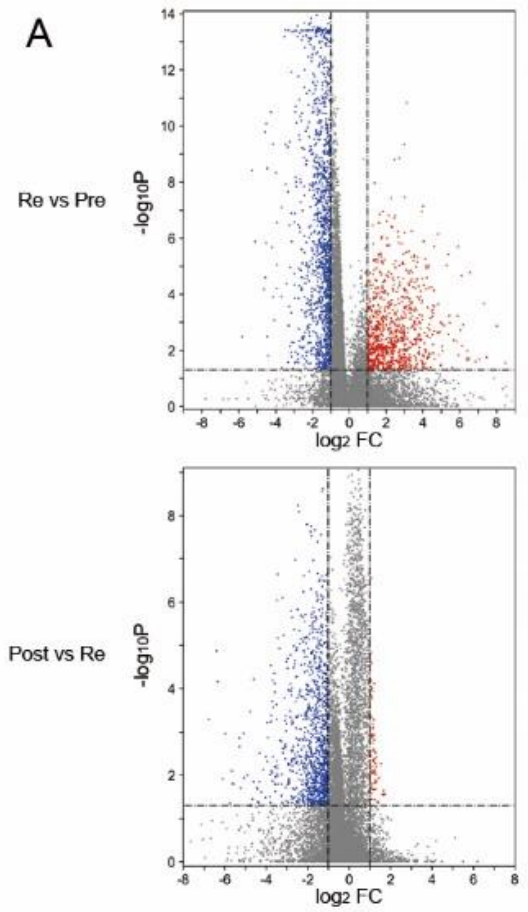

- up-regulated

- down-regulated

- no change

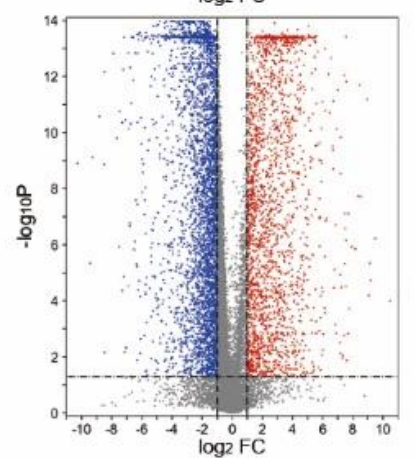

B
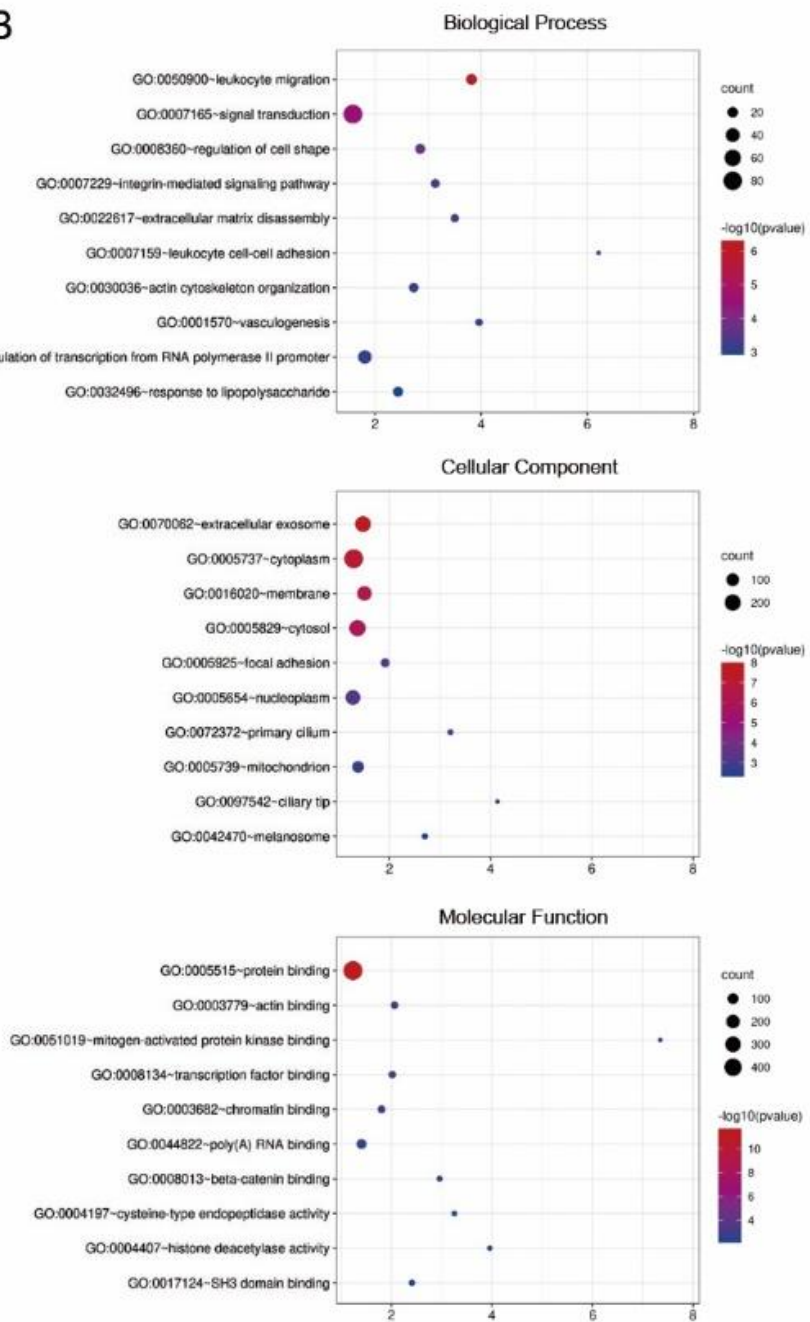

Figure. 2. Differential expression analysis and functional enrichment among endometrial receptivity conditions. 
medRxiv preprint doi: https://doi.org/10.1101/2021.03.07.21253097; this version posted March 9, 2021. The copyright holder for this preprint (which was not certified by peer review) is the author/funder, who has granted medRxiv a license to display the preprint in perpetuity. All rights reserved. No reuse allowed without permission.

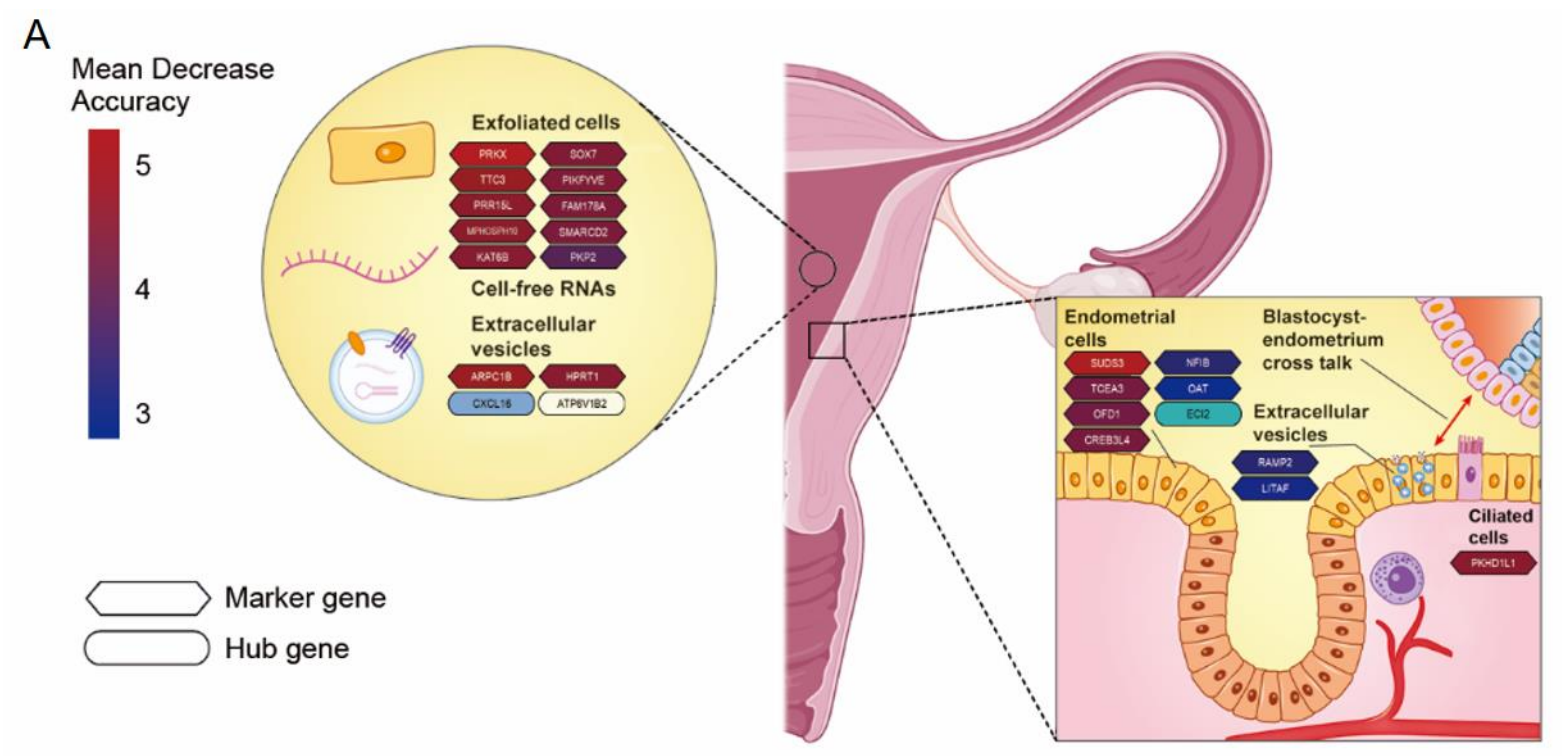

B
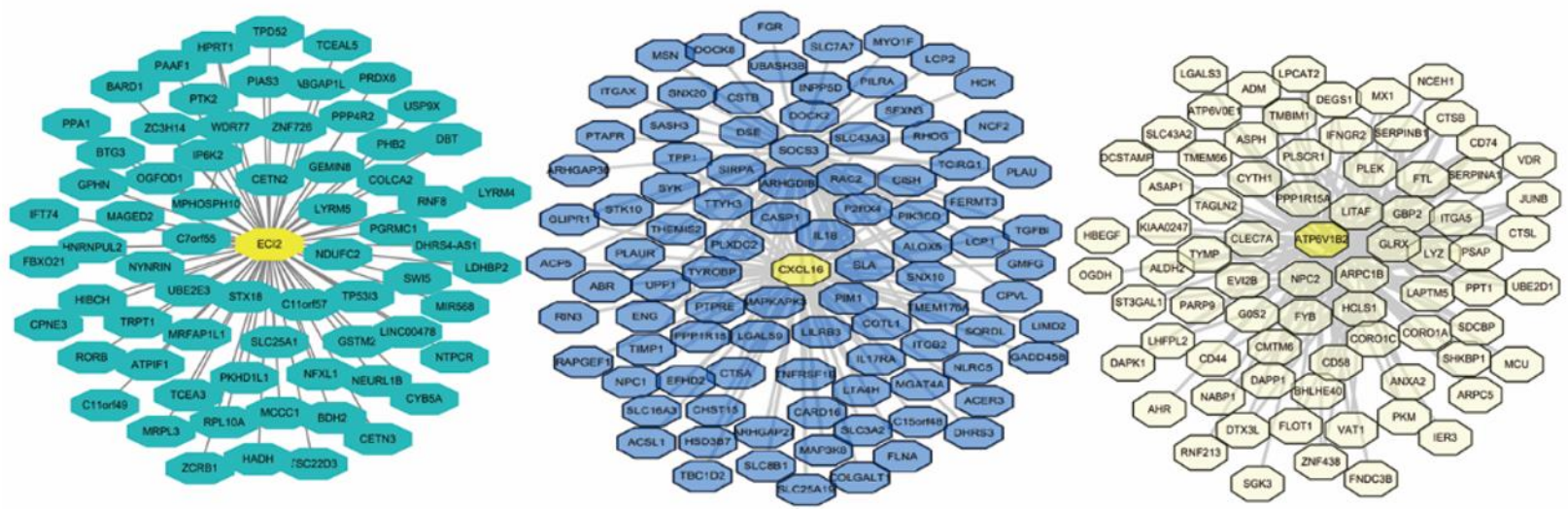

506 Figure. 3. Partial predictive markers of nirsERT. A. Inferred source of marker and hub genes in nirsERT; B. 
A

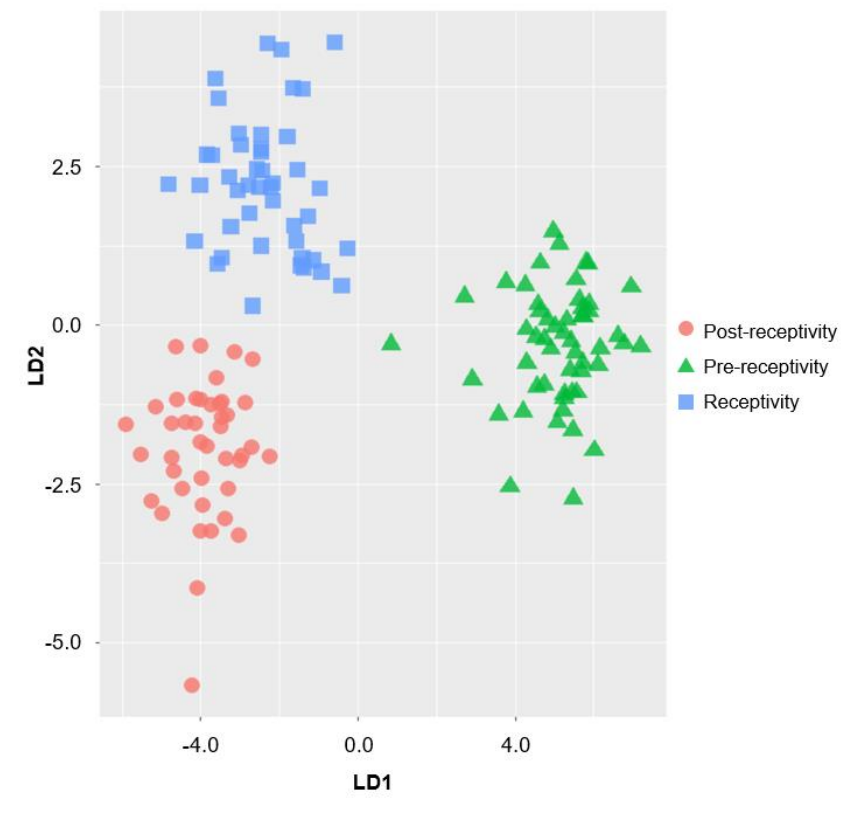

B

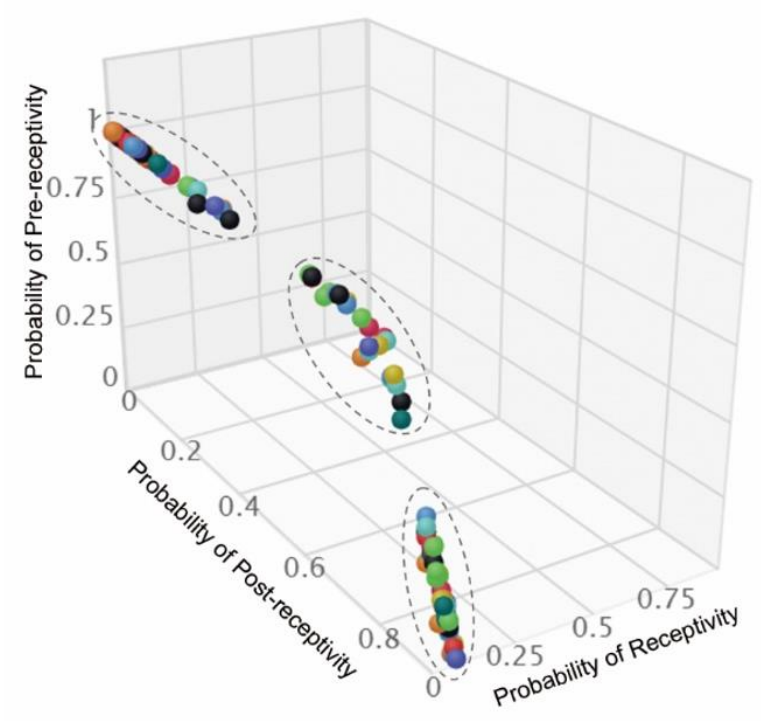

511 Figure. 4. Establishment and validation of the nirsERT. A. Clustering the training set with LDA by using 512 selected predictive markers; B. Prediction results of training set samples, with probability threshold of 0.6. 